\title{
Historical review of Bukit Timah Nature Reserve, Singapore
}

\author{
G.W.H. Davison ${ }^{1} \&$ P.T. Chew ${ }^{2}$ \\ ${ }^{1}$ National Biodiversity Centre, National Parks Board, \\ 1 Cluny Road, 259569 Singapore \\ davisongwh53@gmail.com \\ ${ }^{2}$ Central Nature Reserves, Conservation Division, \\ National Parks Board, 1 Cluny Road, \\ Singapore 259569
}

\begin{abstract}
Biological interest in Bukit Timah, Singapore, long pre-dated its declaration as a forest reserve (1887) and nature reserve (1951). The administrative and land use changes affecting this fragment of coastal hill dipterocarp forest are described. Boundary changes have determined the areas now supporting primary, old secondary or maturing secondary forest, and account for many of the features described in an accompanying set of papers on the current biodiversity of Bukit Timah Nature Reserve (BTNR). Research interest in the nature reserve continues to be high, with roughly 25 new research projects initiated each year.
\end{abstract}

Keywords: Land use, legal status, administration, tropical rain forest.

\section{Introduction}

Of the original $539 \mathrm{~km}^{2}$ area of Singapore's main island (Corlett, 1992), it has been estimated that its pristine vegetation would have comprised about $82 \%$ dryland dipterocarp forest, 13\% mangroves and 5\% freshwater swamp forest (Corlett, 1991). These figures translate to about $442 \mathrm{~km}^{2}$ of dryland dipterocarp forest, of which only 192 ha $\left(1.92 \mathrm{~km}^{2}\right.$, representing $0.43 \%$ of the original) now remain as primary forest (Tan et al., 2010). It has been estimated that about $20 \%$ of the 192 ha occurs within the Bukit Timah Nature Reserve, BTNR (i.e., 38 ha) and the rest as a mosaic of scattered patches within the Central Catchment Nature Reserve (Tan et al., 2010). It is not untouched, as timber cutting, introduction of alien species, management for visitors, and many other activities have taken place, but it is primary in the sense of forest having remained forest without clearance of tree cover. The other remaining forest in present-day Singapore comprises various types of mixed age secondary growth after a period of forest removal, including overgrown orchards, rubber and oil palm plantations into which many native and alien forest tree species have spread, cleared ground that has reverted to scrub dominated by trees such as Adinandra dumosa Jack, and a patchwork of other overgrown land. 


\section{Physical characteristics}

Lee \& Zhou (2009) recognise ten geological formations in Singapore, three having been laid down in the Lower Palaeozoic prior to emplacement of the Bukit Timah Granite in the early to middle Triassic. Gupta (1992) provides dates of 205 and 271-229 million years for the origins of the granite. Granite includes a range of acid rock types (adamellite, granite, granodiorite, and hybrid types where basic rock has been assimilated within the granite). The term 'Bukit Timah Granite' is used to include both the Central Singapore Granite of which Bukit Timah itself consists, and the Pulau Ubin Granite to the northeast. Most hills in this formation are below $60 \mathrm{~m}$ elevation, but the hills become higher towards the contact zone of Bukit Timah Granite with other geological formations (predominantly the Gombak Norite) to the south and west, culminating in Bukit Timah at $163.6 \mathrm{~m}$ elevation.

Residual soil thickness over the granite ranges from a few metres to more than $70 \mathrm{~m}$ deep, and the granite crops out at the surface in only a few places where Singapore's nine main quarries have previously been located. As can be seen at sites such as the exposed rock faces of Hindhede Quarry, the granite is typically pale grey. It often contains about $60 \%$ or more of feldspar and $30 \%$ or more of quartz. Within Singapore, Granite Porphyry Dykes have only been found at Hindhede Quarry and Singapore Quarry, that in the Singapore Quarry immediately northwest of BTNR being more severely altered than those in the Hindhede Quarry immediately west of BTNR. There is usually a fairly sharp transition between deeply weathered material and slightly weathered bedrock, with only little intermediate weathering zone. The soil surface tends to follow the underlying surface of the bedrock but residual soil thickness is least on steep slopes such as those of Bukit Timah.

Where the forest cover has been disturbed, and erosion has been artificially aggravated, it is more common to see exposed core boulders, often but not always chemically weathered to a smooth rounded surface. Road construction, road traffic, trails and tree falls are all potential triggers for earth movement that requires swift attention so as not to cause further damage. Examples of recent remedial works can be seen at several points along the Summit Road and examples of the underlying granite can be seen at some of these.

The climax vegetation in the region is evergreen tropical rain forest, and that on Bukit Timah can be regarded as Coastal Hill Dipterocarp forest (Ashton, 2013). Together with Mukah Head in Pantai Aceh State Park, Penang, Malaysia, it is one of only two patches of this forest type within legally Protected Areas. So far, studies in the 2 ha plot maintained by the Forest Global Earth Observatory (ForestGEO, formerly known as the Smithsonian Centre for Tropical Forest Science, CTFS) show little evidence of species losses within the core primary forest area, but in common with other somewhat disturbed and isolated fragments the forest shows signs of hyperdynamism (enhanced growth rates and turnover). Trees whose fruits are dispersed by large vertebrates may have been the first to disappear. Where the forest has been lost and erosion has occurred, the exposed soil experiences 
irreversible leaching and the flora of the regrowth differs distinctly from the original forest. All of the secondary regrowth around Bukit Timah (Dairy Farm, Hindhede, Rifle Range) demonstrates this, including the ground flora. Ashton (2013) has suggested that 200 reproductively capable individuals within contact (e.g., for pollen exchange) are required for a sustainable tree species population. In Bukit Timah there must be many native trees not now satisfying that criterion.

As a rather small and isolated conical hill providing little catchment area, Bukit Timah has small streams running off in multiple directions. The streams on different faces of the hill are therefore biologically isolated or partly isolated from one another, except for species that can travel overland (e.g., frogs, dragonflies). Stream lengths are short, and they are being further shortened by erosion cutting back into the hill slopes, while water discharge flows are small. For both terrestrial and aquatic plants and animals, therefore, the small size of the reserve, the lack of connectivity with other forest patches, and the loss of key vertebrates (e.g., large predators, seed dispersers) are problematic.

\section{History of Bukit Timah}

The following history of Bukit Timah relies heavily on the publications by Corlett (1995) and by Lum \& Sharpe (1996). Further information is given by Barnard (2014, 2016).

The founding of Singapore in 1819 was followed by a phase of rapid agricultural expansion, including gambier plantations, pepper, and later on cloves, nutmeg and pineapple. During an early recorded visit to the vicinity of Bukit Timah by Singapore's Resident Councillor, John Prince, in June 1827, the 14-mile (22.5 km) walk took five hours through plantations of gambier, swamps and hills into unpopulated forest (Lum $\&$ Sharp, 1996). Prince and his contractors reached the summit and raised a flag on a tall tree. He recorded that the soils were whitish clay throughout, and mistakenly noted the presence of limestone. He subsequently ordered the summit to be cleared, for the erection of a small shelter (Lum \& Sharp, 1996).

By July 1839 Sir James Brooke noted that gambier plantations had extended around the foot of Bukit Timah, the habitations "like clear specks amidst the woods" and from each arising a plume of smoke from fires engaged in the boiling of gambier (Lum \& Sharp, 1996). The fuel for the fires was timber of forest trees, cut in a largely unregulated manner. By 1840 there was a good road to Bukit Timah, and by 1843 there was a road to the hill summit. Tables and benches were provided, and the clearing of the summit was sufficient to allow excellent panoramic views. A government bungalow was built on the summit by 1856 (Lum \& Sharp, 1996).

Lt. Col. Low, a geologist, reported on the Bukit Timah granite in 1847 . He noted the poor soils and high quartzite content, suggesting poor agricultural potential. It has been estimated that forest cover in Singapore had by then declined to $64 \%$ (Corlett, 1992). At the time of Alfred Russel Wallace's first visit to Singapore (June to 
October 1854), his description of the "wood-topped hills" near to the St. Joseph's Church missionary house at Bukit Timah implies that the surroundings of the hills and their lower slopes had already been cleared of forest (Wallace, 1869). This would be consistent with the accounts by Prince and by Brooke.

Woodcutters were at work at the time of Wallace's visit, and pits had been dug for the trapping of tigers. Wallace (1869) did not mention either the summit road (prepared more than a decade earlier) with clearing, tables and benches, or the summit bungalow (which was present at least by two years after his visit). Van Whye (2014) implies that at just this time the summit road was in disrepair.

In 1879 the Colonial Engineer J.F.A. McNair wrote that a reserve was kept around the hill for climatic purposes. A map dated the previous year, 1878 (National Library Board, Singapore: Accession No. SP000216, Media Image No. 20050000977, Acc. No. 373_000288_SP), shows approximately one third of the hill, on the northeast side, designated as water catchment to protect part of the headwaters feeding into Upper Peirce Reservoir, now (2019) represented by Catchment Stream (Cai, 2019). Several isolated land titles shown on the same map were scattered within what would later become the nature reserve. One such land title (later designated Lot 67-31 but not visible on the 1878 map because of physical damage) was presumably occupied by the Bukit Timah Bungalow. The lot number indicates that the bungalow was not at what is now known to be the true summit, but at the site of the (currently three) radio masts built from the 1950s onwards overlooking Hindhede quarry. Other land titles in 1878 were densely packed near the foot of the hill in the vicinity of what would later become Dairy Farm, Hindhede, and in the area now lying between Rifle Range, Jalan Anak Bukit and Dunearn Road. Shortly thereafter (1882) Nathaniel Cantley, Gardens Superintendent, was appointed to report on the state of forests in the Straits Settlements, and as a result Bukit Timah was one of 14 forest reserves set up within Singapore from 1883 onwards by the newly established Forest Department (Cantley, 1887), as it was considered to represent "the best forests that remain in the Settlement". However, only about one third (122 ha) of the total 847 acres (343 ha) was forested (Corlett, 1995), the remainder being grass and fern (133 ha) or brushwood ( $88 \mathrm{ha}$ ), and Cantley's other recommendations, for legislation and for reforestation of cleared land, were highly necessary for the survival of forest on Bukit Timah. Cantley was appointed Superintendent of the new Forest Department of the Straits Settlements, with four staff as well as Forest Guards and Forest Watchmen in Singapore. A 15 -foot $(5 \mathrm{~m})$ wide fire break was cut for about 6 miles $(10 \mathrm{~km})$ along the forest reserve boundary. Already by 1884 trees (it is implied belian, Eusideroxylon zwageri Teijsm. \& Binn.) were being planted to improve the forest on Bukit Timah (Ridley, 1901). By 1885 about 50 acres (20 ha) of degraded land, and by 1886 another 70 acres (28 ha), had been planted up with teak, rain trees and mahogany (Lum \& Sharp, 1996).

By 1889 the total area of forest reserve land in Singapore was 12,965 acres (5250 ha) or roughly $10 \%$ of the land area, and Bukit Timah was one of nine forest reserves whose boundary paths were found to have been incorrectly surveyed (Ridley, 1890). These were corrected, cleared of weeds, the streams bridged, and the forest reserve constantly inspected. 
Bukit Timah in 1889 consisted "of a patch of very good virgin forest containing bilian wangi [Aquilaria malaccensis Lam.], kranji [Dialium indum L.], meranti [Shorea spp.], bintangor [Calophyllum spp.], getah Taban [Palaquium gutta (Hook.) Baill.], rengas [Gluta spp.], mahang [possibly referring to Macaranga gigantea (Rchb.f. \& Zoll.) Müll.Arg.] and trees of less value, and a large extent of lallang [Imperata cylindrica (L.) P.Beauv.] and secondary forest" (Ridley, 1890). In 1890 some brushwood and some newly planted seed lines were burnt during bush fires (Ridley, 1891). In 1892 a Forest Station at Bukit Timah was one of four built during the year, at a cost of $\$ 290$ each. A nursery was started at Bukit Timah in which 6,000 seeds of belian obtained from Mr W. Pryer in Sandakan were planted, and seedlings of this Bornean endemic tree raised from a small quantity of seed were planted there and in some of the other forest reserves (Ridley, 1893). In 1893 a total of 2,270 young belian trees were planted on Bukit Timah (Ridley, 1894), and in 1894 a further 1,000 belian plants, that had not been large enough in 1893, were planted out in Bukit Timah and Bukit Mandai (Fox, 1895). The young trees that had been planted in former years were maintained by weeding.

In accordance with the recommendations of the Retrenchment Committee, the forests were handed over, from 1st January 1895, to the charge of the Collector of Land Revenues (Fox, 1895), indicating a focus on revenue generation rather than conservation. In the first annual report under the new administration, Innes (1896) reported that there was a large fire on the west of Bukit Timah; together with another at Jurong, these two fires totalled 300 acres (122 ha). There were six Forest Guards under one Forest Ranger to take care of the 8491 acres (3439 ha) of forest in the Western Division (two thirds of the total), of which 847 acres (343 ha) were in Bukit Timah Forest Reserve (Michell, 1898). Ten acres (4 ha) were burnt in 1897, a suspect arrested, but the case was dismissed due to insufficient evidence (Michell, 1898). Ten inspections were made by the Forest Ranger during the year, and there were four arrests, presumably for illegal woodcutting. Such statistics are not available for every year, but these illustrations from a single period show the continual pressures on the staff to conserve the remaining forest. The headquarters was maintained at the site where it had been built in 1892, at Bukit Timah Road, $63 / 4$ mile post, on the right side of the road proceeding from town (behind Bukit Timah police station).

The Collector of Land Revenues reported that just half an acre of scrub in Bukit Timah was burnt in 1899 (Carter, 1900), considered an example of successful enforcement, but it is clear that although the forest reserve came under the jurisdiction of the Collector of Land Revenues, Ridley was still undertaking the major role in forest management there. In 1899 he imported "a number of sticks of gutta percha, Dichopsis sp. [= Palaquium sp.] from Borneo, coated in mud and stored in gunnies". They were planted out and watered, some grew roots and shoots, and some of them were later planted out in Bukit Timah Forest Reserve (Ridley, 1900). About three acres (1.2 ha) of ground at the base of the hill were cleared of scrub, dug and planted with gutta percha plants. The belian trees formerly planted there were freed from the overcrowding jungle, and the merbau and other trees cleaned, and dug round. 
Para-rubber [Hevea brasiliensis (Willd. ex A.Juss.) Müll.Arg.], tembusu [Cyrtophyllum fragrans (Roxb.) DC.] and other trees were planted in suitable places (Ridley, 1900).

Ridley (1901) continued to plant and maintain gutta percha and rubber, for which he obtained a grant of Straits $\$ 300$, and also planted valuable timber trees in those places considered unsuited to gutta percha or rubber, for which he obtained a second grant of $\$ 300$. The small vote for gutta percha and rubber planting allowed three men to be employed in 1900 to clear the forest on the lower slopes of Bukit Timah, and plant as many trees of getah taban (another local name for gutta percha, and the tree after which Taban Trail is named) as were procurable. The trees planted in 1899 were cleared and as far as possible replaced where they had died, and the trees growingon the eastern slope of Bukit Timah were inspected, the shrubs and jungle trees which were crowding them out wercleared away, and a number of over-crowded young plants were removed from that locality and transferred to the new plantation. The ground on the left side of the road going up to Bukit Timah hill proved less suitable for the growth of getah taban than had been expected.

Ridley (1901) recorded with regret "the destruction of five fine large sized trees in the Bukit Timah Forest.... With the present value of gutta percha, severer penalties and a more adequate staff of Forest Guards will be required to prevent the destruction of the remaining large trees".

The vote for planting valuable timbers in the forests, viz., Straits $\$ 300$, allowed another three men to be employed on that work. "The ground was cleared where necessary, in the same district of the Bukit Timah Forest Reserve which was selected for the planting of gutta percha, the ground unsuited for that species being planted with timber trees. Altogether an area of about 60 acres was opened up and planted and 15 acres planted on the previous year was cleared and the trees weeded. The chief trees planted were Mahogany (large-leaved) [Swietenia macrophylla King]17,600; merbau [Intsia palembanica Miq., or possibly I. bijuga (Colebr.) Kuntze was meant] 6,800; Eugenias [Syzygium spp.] and various plants 982; rengas [Gluta spp.] 300, all raised from seed, and 1,380 balam [sic; misprint = balau, Shorea spp.] removed from the Botanic Gardens were also planted. The Mahogany and merbau made very satisfactory growth and there were only a few failures" (Ridley, 1901).

In 1901 the merbau trees at the old plantation by the Bukit Timah Forest Station were opened up, the scrub and other trees growing round them and interfering with their growth were removed, and the few belian trees on Bukit Timah which had survived the encroachment of fern and scrub were also cleared round, and quickly showed signs of increased growth; unfortunately, the greater number planted in 1884 succumbed to want of clearing in the following years.

For the first time in the history of Singapore, in 1901 seeds of "the true Dichopsis gutta" [Palaquium gutta] were gathered from a tree in the Botanic Gardens (Fox, 1902), which was the direct descendant of the original trees at Bukit Timah which gave the first gutta percha brought to the notice of science, and on which the genus Dichopsis was founded. The six men employed at Bukit Timah planted 14,000 trees, chiefly gutta percha, in 1902. The young trees were cleaned up and the paths 
opened where they had got covered. As a portion of the reserve was alienated by Government for coolie lines of the quarry, all the trees on it that could be moved were transferred (Ridley, 1903). gutta percha seeds were obtained both from the Botanic Gardens and from trees in the forest, although many were carried off by fruit bats Cynopterus brachyotis before they were ripe. At the end of 1902, the plantation at Bukit Timah was transferred from the Botanic Gardens to the Forest Department (Ridley, 1903), and subsequent annual reports transfer their attention to the planting and experimentation on Para rubber in the Gardens.

Altogether, therefore, 48 ha of land had been planted up in the period 18841886, involving an unknown number of belian, teak, rain trees and mahogany. Approximately 43,000 trees had been planted in the period 1893-1902, covering an uncertain area but including belian, balau, gutta percha, mahogany, merbau, rengas, rubber, tembusu and Eugenia. While the site of the belian nursery is known in the southwestern part of Bukit Timah Nature Reserve, none of the planted trees seems to have survived long and the extent of the broader scale planting work (i.e., extending beyond the nursery into the forested slopes) is not mapped.

From 1908 onwards, the protection of Bukit Timah as well as the other forest reserves came under a new Forest Ordinance under the Forest Department. At this time the Singapore-Johore railway was being built (completed in 1909), requiring wood for sleepers, and setting a definitive limit on forested vegetation on the western side of Bukit Timah. Also in 1909, 130 acres (52 ha) on the northeast side of Bukit Timah were transferred to the control of the Water Department under the Singapore Municipality, as an extension to the water catchment area feeding MacRitchie Reservoir, apparently the same area that had appeared on the 1878 map referred to above.

However, in 1931 a discussion had been initiated within government debating whether to revoke all forest reserves in Singapore, as they could not generate revenue from timber production, were expensive to maintain, and too difficult to protect from encroachment and illegal cutting. The decision was taken in 1936, effectively removing any protection for Bukit Timah. The scientific staff from the Gardens Department fortunately stepped in, and the management of 250 acres (100 ha) of forest was taken over by them in the following year (Corner, 1938). It was at this time that Holttum discovered a man was being paid to keep the Taban Valley free from undergrowth, for ease of collection of gutta percha seeds, even though no seeds had been collected by the Forest Department for many years. According to Lum \& Sharp (1996) traces of the original nursery and plantation could still be seen in the Taban Valley sector of Bukit Timah, on the right of the entrance, some trees still bearing herringbone tapping scars.

Bukit Timah and two mangrove areas, one at Kranji ( $14^{\text {th }}$ mile Woodlands Road $)$ and the other between the Pandan and Jurong rivers, were then gazetted as Forest Reserves "primarily for the preservation of typical areas of natural vegetation, and control [was] entirely in the hands of the Gardens Department in 1939 with the Director of Gardens designated as Conservator of Forests" (Holttum, 1940). 
On the southwestern side, always the main access point to Bukit Timah, the limits to contiguous vegetation had been established by the position of Upper Bukit Timah Road, and latterly by the position of Hindhede Quarry and Hindhede Road. In 1932-1936, at the same time that discussion was active on degazettement of the forest reserves, the railway route that had been aligned to the west of Upper Bukit Timah Road was realigned so that it ran further east, behind the fire station and factories, close up against the boundary of Bukit Timah Forest Reserve. The realignment required construction of a bund or embankment along low-lying stretches, and a new iron truss bridge over Hindhede Road that is still in place today. Construction of the embankment and bridge would have occurred while Holttum was in discussion with the rest of government about the future of the reserve. It would have affected the alignment of the Rail Corridor stream referred to by Cai (2019) that now runs close and parallel to the foot of the embankment for much of the distance between Rail Mall and Hindhede Drive.

On the southeastern side of Bukit Timah, the rifle ranges were in place by the 1930s. After pre-war use by the military for ammunition storage, the ranges were leased to the Singapore Gun Club from the early 1950s, until August 2001. The site has now been occupied by the Temasek Club, operated by the Singapore Armed Forces Recreation Association (SAFRA).

During the Second World War, Holttum prepared monthly reports on the activities of the Botanic Gardens. Bukit Timah is occasionally mentioned, as for example in August 1942 when a specimen of Deplanchea bancana (Scheff.) Steenis was brought from Bukit Timah for planting in the Gardens near the bandstand; the species is now extinct in Singapore. Each report describes the scientific activities of Holttum and of Dr Furtado in detail, but Corner is mentioned largely in his absence assisting Dr Kwan Koriba in his studies of Malayan plants, including visits to Bukit Timah. In June 1942 Corner managed to obtain permission to employ six labourers (virtually equivalent to pre-war levels) at 55 cents each per day, but this staff level was rarely achieved: later in the war it was down to two labourers, only one if the other was sick. In such a situation it was difficult to prevent squatters raiding the forest for firewood, and the Gardens' staff member in charge of the reserves, Che Ngadiman, frequently reported losses. Reporting these to the Japanese authorities had only a temporary dampening effect, and in the closing months of the war the tone of the monthly reports changed subtly from preventing unauthorised felling to merely preventing unnecessary felling, for without firewood it was impossible to cook. At the same time Corner was visiting the reserves by motorcycle, for which he was given an allowance of fuel, and worked mainly on fungi, as well as palms and legumes. The Japanese military forces had performed some excavation work at the summit and dug a cave tunnel off the Jungle Fall track (it was eventually sealed off from public access in 1980 because of safety concerns). When Corner went again to Bukit Timah after the war, he reported being shocked at the amount of unexploded ordinance lying about. A start on clearing this became possible in 1946-1948 when Holttum was fully in charge again. 
When the Nature Reserves Ordinance was passed in 1951, the three areas of Bukit Timah, Pandan and Kranji, together with Labrador cliff and the central water catchments were administered by trustees who constituted a Board of Management of the Nature Reserves with the Director of Gardens as chairman (Henderson, 1952). The Nature Reserves Board (as it was usually referred to), and the scope and purpose of the nature reserves, were then formalised by the Nature Reserves Act (Cap. 295) 1955 for the propagation, protection and preservation of the indigenous fauna and flora, and for study and research into matters relating to the fauna and flora of Singapore and the physical conditions in which they live. Henderson (1951) reported that a police wireless station was constructed in 1950 on the summit of Bukit Timah and, "as this area was once the site of a house", there were no trees of value upon it and no interference with the native forest resulted. All the reserves were maintained satisfactorily. Thefts of timber were considered not serious. Bukit Timah Bungalow still stood in 1955 but it was damaged and derelict, and although members of the Nature Reserves Board assumed the bungalow would pass to them, they discovered that several other agencies had designs upon it. Purseglove $(1956,1957)$ wrote that "The Bukit Timah bungalow and its land (Lot 67-31) has now reverted to the Crown and formal application has been made for it to be included in the reserve. The bungalow would prove a useful resthouse for scientists and others." However, it was passed to the police radio station on the understanding that the site would be accessible to the public. Strangely, no definitely identifiable photograph of the bungalow seems to exist.

The total area had been reduced to 75 ha (Henderson, 1952; Purseglove, 1956); this was apparently its area throughout the 1950s to 1970s. During those decades the Nature Reserves Board employed supervisory staff, up to three rangers and seven to nine labourers, for patrolling, to avoid fires and timber thefts, and to maintain trails. Shelters, maps and signboards were visible signs of public outreach. The Board included many well-known names such as Yusof Ishak (future President of Singapore), M.W.F. Tweedie (staff member of the Raffles Museum), Prof. H.B. Gilliland of the university, and Directors of the Botanic Gardens including in succession M.R. Henderson, J.W. Purseglove and H.M. Burkill. Later Mr Wong Yew Kwan and Mr Quek Kiah Huat were energetic chairmen, supported by Hardial Singh and in the 1970s by Dr Chang Kiaw Lan. The entry of new members onto the Board was facilitated by Mr A.G. Alphonso, whose 'corporate memory' of the history and functions of the Board smoothed their transition. A summary in 1959 reported that timber thefts continued to be the main threat inside the reserve and quarrying the main external threat. The small size of the reserve was seen as the main threat to its long-term future, because of changes in microclimate. To this was added the fact that spent cartridges were often found by the workers, but shooters of wildlife could never be apprehended.

Quarries appear to have begun operating successively between 1900 and 1920, for which latter year a map is available showing some of the quarries already of a large size. Granite was required for the reconstruction of Singapore Harbour, at Tanjong Pagar, for construction of the Causeway at Woodlands, for railway ballast, and for road chippings (Lum \& Sharp, 1996). There were three main quarries nearby, now known by the names Singapore Quarry, Hindhede Quarry and Dairy Farm Quarry. Up 
to five quarries round Bukit Timah are mentioned in old reports, but these might have included the ones at Bukit Batok and Rifle Range, and possibly more than one worked face within a single quarry. Blasting was used to break off large sections of granite for breakdown into rocks and chippings. There were calls for cessation of operations from the 1930s onwards, and during the 1950s and 1960s there were frequent references to imminent closure of the quarries; yet another 20 to 40 years were to elapse before this was put into effect. Government files are often staid and tedious, yet one puts down the correspondence from 1940 to 1964 with a racing pulse and a sense of awe at the literary skill displayed in the exchanges on quarrying. Holttum, Henderson, Addison, Gilliland and Burkill, either as Directors of the Gardens or on behalf of the Board of Management of the Nature Reserves, evidently spent much of their time on Bukit Timah in fending off proposals for new quarries, applications for lease extensions of existing quarries, demands for more land and forest to be taken away from them, with insults and blasted rocks flying in all directions. Singapore Railways, and even the navy and the air force, came under fire. Dairy Farm Quarry ceased operations in the early 1970s, and the cavity was filled with earth. Singapore Quarry ceased in the late 1970s and remained as a lake, but it was not incorporated into a nature park until 2005. Hindhede Quarry, the most directly damaging to the nature reserve, ceased by 1990 but remained as a lake (the surface area is approximately $3 \mathrm{ha}$, and the depth reaches $18 \mathrm{~m}$ below mean sea level), and it was quickly incorporated into Hindhede Nature Park in 2001. The lakes at Singapore Quarry and Hindhede are not supplied solely by surface run-off, but by streams (Jungle Fall stream flows into Singapore Quarry) as well as underground percolation. The quarries were considered to be responsible for loss of forest reserve area, loss of habitat, soil erosion, altered hydrology and changes in microclimate as well as interference with access, damage to the summit road, and increased risk of landslips.

By 1956 quarrying at Hindhede had proceeded downwards to a point where it compromised the safety of the ascent road. An attempt was therefore made to realign the ascent road beginning from the nature reserve's labour quarters [close to the existing visitor centre]. This proved to be dangerously slippery for all but four-wheel drive vehicles, and repeated representations were made for realignment and for hard surfacing. In 1956, at least part of the road was surfaced to a depth of 6-8" and a width of 8 feet. Further work was done in 1964 and 1976, partly with concrete or cement and partly with tarmac. On the Summit Road (its official name is correctly Hindhede Drive, as approved by the Rural Board in 1960), past cuttings into the embankment alongside can now be seen where minor realignments of the road have occurred. The road at this time was open to use by private vehicles, and it was only in the early 1970 s that this could be halted, in order to safeguard pedestrians. The nature reserve continued to be used for military training until at least 1974, and this also involved vehicles using the summit road. Vehicles were restricted to limited daytime hours in 1970, and the road was finally closed to all but police and vehicles servicing the radio installations in late 1976.

The southwestern side of Bukit Timah outside the reserve boundary had always been the most heavily settled part. Ridley's nursery was nearby, and staff quarters (last 
occupied in 1973-1974) were beside the site of the existing visitor centre. Squatters occupied what is now the nature reserve car park, the land from there down to the railway, with one or two squatter houses built just inside the reserve. Until at least the 1970s a spur line from the railway fed off to take granite product away from Hindhede Quarry, and several associated factory buildings were clustered round it. 'Kampong Quarry', now expunged, sat in a small triangle of land between Hindhede Road and the main railway line, and presumably a number of the residents there and in the surrounding land worked at the quarry.

Through the 1960s and 1970s it can be assumed that visitor numbers were increasing, a visitor centre being first built in 1961, but visitor numbers were not recorded. Rising public interest was not sufficient to protect the reserve: in 1980 the Nature Reserves Board was informed of plans to create a new expressway that would, in their estimation, remove 86 ha of forest. Representations for an alternative route were rejected, and in 1983-1986 the construction of the Bukit Timah Expressway (BKE) isolated Bukit Timah Nature Reserve from what had been the Water Catchment Area, later the Central Catchment Nature Reserve. This was a major event in the biological history of Bukit Timah Nature Reserve, and it was followed by demonstrable local extirpations, for example of the monkey Presbytis melalophos; though not causing the loss, when the last individuals died there was no source population available to supply recruitment and no route for recolonization of the reserve.

The Nature Reserves Act had been amended repeatedly in the 1950s and 1960s, but primarily to make changes in the system of appointments to the Board, as the administration of Singapore shifted from Chairman in Council to Governor to President. The Act was repealed in 1990 with the amalgamation of Singapore Botanic Gardens, the Parks and Recreation Department, and the Board of Trustees of the Nature Reserves to form a new National Parks Board (Lye, 1991). Conservation, research, education and public use of the nature reserves were for the first time consolidated under a single government agency, and the size of Bukit Timah Nature Reserve was settled at 163 ha, a doubling of the area protected in the 1950s and 1960s. Although the Nature Reserves Board, with appointees by the President, ceased to exist as such, a Nature Reserves Committee continued an advisory function and was active intermittently until at least 1996.

Two aerial photographs reproduced in LaFrankie et al. (2005) show the effects of reducing land use intensity around the core of the nature reserve from 1950 to 1993. The 1950 image shows very sharply defined boundaries between the 81 ha nature reserve and the cleared ground of the Dairy Farm to the north and of Rifle Range to Jalan Anak Bukit to the south. The cleared land to north and south left the nature reserve as a narrow neck of forest less than $400 \mathrm{~m}$ wide at its narrowest point. However, the vegetation, though interrupted by a narrow clear track over the pipelines was contiguous with that of the Central Catchment. By 1993, tree cover had grown up tremendously over both Dairy Farm and Rifle Range, creating woodland of a sort over about 340 ha of land including the 163 ha nature reserve. The track over the pipeline, however, had been broadened, and the Bukit Timah Expressway formed a much harder boundary to the east. By 2018, satellite images show that intermittent 
clearing (2001-2002) in the Rifle Range area to the south had regrown; the Temasek Club building at Rifle Range had been completed, but on the other hand the area of buildings at Dairy Farm had been much reduced. Dairy Farm Road had been widened to form a hard boundary on the north.

To the northeast, the idea of an 'EcoLink' bridge across the Bukit Timah Expressway between BTNR and the Central Catchment Nature Reserve was discussed during preparation of the 'Singapore Green Plan 2012' (MEWR, 2006) and supported by the Garden City Action Committee (GCAC) in 2005. Funding was secured the following year, and an ecological feasibility study was commissioned by the National Parks Board, conducted by experts from the National University of Singapore, landscape planning consultants and environmental impact consultants. The designs were developed in consultation with the Land Transport Authority. The EcoLink@BKE was constructed beginning in 2008 and completed in October 2013. It is an attempt to redress some of the physical and genetic isolation of populations caused by construction of the Bukit Timah Expressway by providing a land link with the Central Catchment Reserve. It bridges the six-lane dual carriageway and is approximately $50 \mathrm{~m}$ wide at its narrowest point. The top is covered with a deep soil layer and supports dense mixed tree cover. A monitoring programme has been conducted by the National Parks Board to determine animal movements across the EcoLink. Camera trapping and other methods have shown that animal movements are taking place, so that gene flow for some species has improved.

In 2013 National Parks Board (NParks) invited several knowledgeable individuals to sit on a new Nature Reserves Scientific Advisory Committee, NRSAC. It is chaired by one of its members who is not on the staff of the National Parks Board. It has no formal powers but is meant to advise the Board on research and scientifically based management requirements. The membership is not fixed but for efficiency it is kept small.

Figure 1 shows the extent of Bukit Timah Forest Reserve and later BTNR at different dates. The area originally protected in 1887 included much non-forested land and 'brushwood' (Corlett, 1995). Excision of the catchment area referred to in the 1878 map described above, and formally transferred to the Water Department in 1909 , is clearly visible on the northeast quadrant (coloured yellow, stippled). The long narrow rectangle occupied by the rifle ranges on the south side was already visible by 1887. By 1938 the area protected had been reduced to less than $20 \%$ of the original. Progressive increases thereafter can be traced by comparing Fig. 1 here with the map in Chan \& Davison (2019), showing that the structurally and floristically determined vegetation zones roughly correspond with the step-by-step historical administrative changes. Primary forest is virtually exclusive to the area that has always lain within the boundaries of the protected area, whether as forest reserve or nature reserve. Areas outside the nature reserve but within Dairy Farm and Rifle Range Nature Parks are predominantly young growth classed as maturing secondary forest. The bulk of old secondary forest is in the intervening zones. By 2006 the area of BTNR was about $48 \%$ the area of the original forest reserve, but by 2018 the addition of the surrounding nature parks had brought back the total greenery to $90 \%$ of the original. 


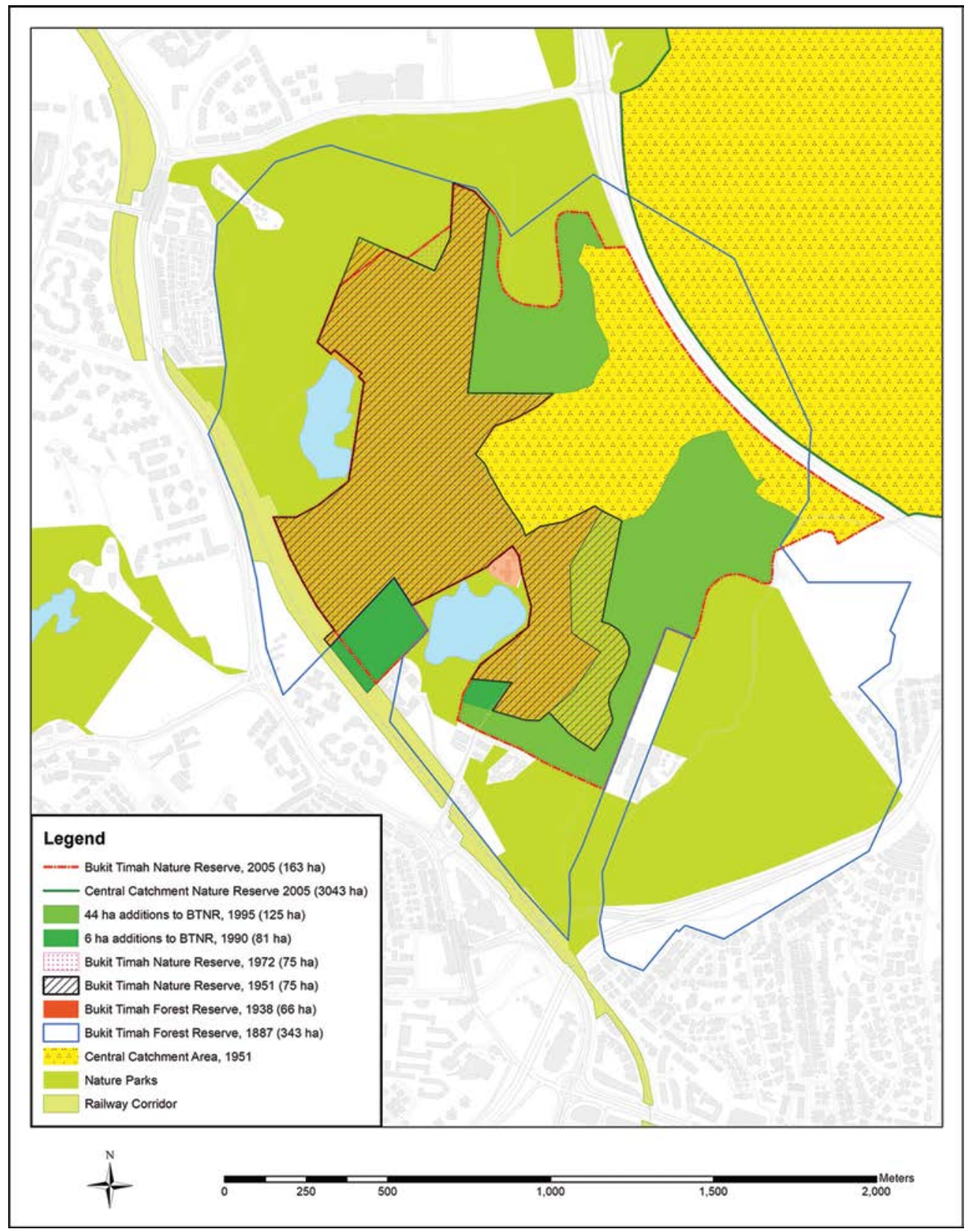

Fig. 1. Map showing progressive boundary changes and areas of Bukit Timah Forest Reserve / Bukit Timah Nature Reserve from 1887 to 2006. (Source: P.T. Chew/ NParks) 


\section{Present situation}

Bukit Timah Nature Reserve now covers 163 ha (403 acres), more than double its size in 1951-1995. The summit road (with spur road to the Telecomms towers) is the only tarmac surfaced road within the reserve. Immediately adjacent are Hindhede Nature Park including Hindhede Quarry (9.5 ha, of which the quarry lake occupies about 3 ha); Dairy Farm Nature Park including the Singapore Quarry, the infilled Dairy Farm quarry and the Wallace Education Centre (reported area 63 ha); and Rifle Range Nature Park (reported area 69 ha) including the now infilled Sin Seng quarry. Analysis of spatial data from Geographical Information Systems (GIS) suggests actual areas of 76 ha for Dairy Farm Nature Park and 65 ha for Rifle Range Nature Park, and these are the figures reflected in Table 1.

Together, BTNR, Dairy Farm, Hindhede and Rifle Range Nature Parks represent 314 ha (775 acres) of largely contiguous forest, within which the chief breaks are caused by the Summit Road (Hindhede Drive), Rifle Range Road, the Wallace Education Centre and its access track, buildings round the Ministry of Education's former Dairy Farm Adventure Centre, and the Temasek Club on the site of the former rifle range. The perimeter of this block of mostly secondary forest is marked by Dairy Farm Road to the north; Upper Bukit Timah Road, the former railway line and Hindhede residential area to the west, Bukit Timah Expressway and adjacent water supply pipelines to the east, and the Pan Island Expressway and Murnane Service Reservoir to the south and southeast. The nature reserve is ringed by a mountain biking trail that is off limits to pedestrians and has a length of $7 \mathrm{~km}$.

The acquisition and management of the nature parks (Hindhede, Dairy Farm and Rifle Range) are a key part of the current conservation strategy for BTNR. Secured one by one, through concerted efforts by several government agencies, they contain the bulk of maturing secondary forest as defined by Chan \& Davison (2019) that has begun recovering since closure of the quarries. As the nature parks containing this forest have fewer of the animal and plant species characteristic of primary coastal hill dipterocarp forest, they provide an opportunity to draw visitor pressure away from the core of BTNR to the periphery, as well as buffering physical edge effects (e.g., microclimate) and extraneous disturbance (e.g., light and noise pollution). As mentioned in other papers in this volume, the nature parks add to total species diversity and provide further ecological resources (e.g., bright sunny forest canopy breaks, and perpetual flower, pollen and nectar sources) that help species such as butterflies and bees within the core of BTNR to tide over lean periods.

It is likely that BTNR and the Nature Parks benefit from the presence of Bukit Batok Nature Park to the west (separated by Upper Bukit Timah Road), and exchange of fauna with the Central Catchment Nature Reserve to the east (separated by the Bukit Timah Expressway) has been documented during surveys of the EcoLink. Bukit Batok Nature Reserve acted as an alternative recreational venue during the temporary closure of BTNR, and probably still helps to alleviate visitor pressure on BTNR after the re-opening. Together Bukit Batok Nature Park, BTNR and its adjacent Nature Parks (Dairy Farm, Hindhede, Rifle Range), and CCNR and its adjacent Nature Parks 
Table 1. Extent of Bukit Timah Forest Reserve (1887-1938) or Bukit Timah Nature Reserve (1951 to the present day).

\begin{tabular}{|c|c|c|c|}
\hline Name & Year & Area (ha) & Event \\
\hline \multirow[t]{2}{*}{ Bukit Timah Forest Reserve } & 1887 & 343 & $\begin{array}{l}\text { First creation of forest reserves in } \\
\text { Singapore }\end{array}$ \\
\hline & 1938 & 66 & $\begin{array}{l}\text { Allocation to Singapore Botanic } \\
\text { Gardens after degazettement } \\
\text { 1936-38 }\end{array}$ \\
\hline \multirow[t]{5}{*}{ Bukit Timah Nature Reserve } & 1951 & 75 & $\begin{array}{l}\text { Passage of Nature Reserves } \\
\text { Ordinance }\end{array}$ \\
\hline & 1972 & 75 & \\
\hline & 1990 & 81 & Creation of National Parks Board \\
\hline & 1995 & 125 & $\begin{array}{l}\text { (Addition of E1 \& E2 land } \\
\text { parcels) }\end{array}$ \\
\hline & 2006 & 163 & $\begin{array}{l}\text { Revision of Parks and Trees Act } \\
\text { (inclusion of excised catchment } \\
\text { portion from CCNR) }\end{array}$ \\
\hline $\begin{array}{l}\text { Area inclusive of BTNR, Dairy } \\
\text { Farm Park, Rifle Range Park } \\
\text { and Hindhede Park }\end{array}$ & 2018 & 314 & $\begin{array}{l}\text { Creation of surrounding nature } \\
\text { parks buffer, } 2001 \text { onwards }\end{array}$ \\
\hline
\end{tabular}

(Chestnut, Windsor, Thomson, Springleaf) form the largest block of forest vegetation in Singapore with only two intervening main roads. Pollen, pollinator and seed exchange are all likely though difficult to demonstrate.

An informal estimate by the chairman of the Nature Reserves Board in the mid- 1960s (on file in the Library of Singapore Botanic Gardens) suggested that about 200 people visited Bukit Timah Nature Reserve every Saturday and Sunday, but few people came during weekdays. If the rough figure is accepted as about 500 people per week, this is equivalent to 26,000 visitors per year. By 1990 the number had climbed to 80,000 people, by the year 2000 to 225,000 people, and by 2004 to more than 400,000 people. Numbers then fell a little until data collection was interrupted in 2010, but this period coincided with development of visitor facilities at Dairy Farm, Singapore Quarry and Bukit Batok Park that, as intended, drew off some visitors and may have reduced impacts within the Nature Reserve.

Management tools to enhance the conservation of BTNR include (1) the closure of the reserve for major works such as slope repairs, (2) pre-emptive steps to prevent slope failure, (3) the temporary closure of particular trails for soil rehabilitation 
and stream restoration, (4) the implementation of the Forest Restoration Action Plan that focusses on the planting of native tree saplings to strengthen the resilience of the native ecosystems, (5) the creation of links with nearby forest patches, including the Eco-Link@BTNR with the Central Catchment Nature Reserve, Bukit Batok Nature Park, etc., (6) management of alien invasive species in the buffering nature parks, and (7) native tree planting in the nature parks to improve forest structure in the long term and to complement the ecosystems found within the core BTNR. Of these, only a partial list, some are rare and occasional interventions, while others are continual and ongoing.

\section{Biological information}

The earliest known biological work thought to have been conducted on Bukit Timah was the collection activity by Alfred Russel Wallace in 1854. Wallace's mode of support was to collect specimens (mostly of animals and few plants) for sale through his agent to collectors in Britain and Europe. He therefore placed emphasis on taxa that would be appealing, saleable, and readily collectable. This system was his means to an end, the scientific study of nature, and he therefore took care to arrange that his specimens reached the attention of specialists (e.g., Deyrolle, 1864; Hewitson, 1865; Pascoe, 1864-1869; Smith, 1857, 1858, 1863; Walker 1856a, 1856b, 1856c, 1859). Together, such papers constitute a first comprehensive survey of the Singapore invertebrate fauna, assumed to be largely from Bukit Timah and its vicinity but the publications are sometimes vague on geography.

The next large-scale biological investigations were floristic and taxonomic studies of plants by Ridley during the time in which he used Bukit Timah as a testing ground for gutta percha and rubber, but he meanwhile collected herbarium specimens, described new plant species, and incorporated results into his Flora of the Malay Peninsula (Ridley, 1922-1925). It was this that made Bukit Timah famous as possibly the richest site in the world in terms of number of type localities per unit area. After R.E. Holttum joined the Singapore Botanic Gardens in 1922, and E.J.H. Corner in 1929, both of these eminent botanists conducted part of their research in Bukit Timah Forest Reserve, the former concentrating on the understorey flora and the latter studying macrofungi, trees, and making herbarium collections with the help of trained pig-tailed macaques. Holttum may have used the forest reserve to plant out living collections of gingers and other plants brought from other parts of the Malay Peninsula, while Corner concentrated on tree phenology, identification and labelling for scientific and educational purposes. Plant identification at Bukit Timah was continued by Holttum into the 1950s. It is remarkable that, after the planting of thousands of saplings of Eusideroxylon zwageri, Syzygium grande, Palaquium gutta, Hevea brasiliensis, Cyrtophyllum fragrans and other trees by Ridley, effects of that tree planting programme have not been revealed by the subsequent work of Holttum, Corner, or LaFrankie et al. (2005).

Other than large organised surveys, Bukit Timah Nature Reserve has been a focus for research by Singaporean and overseas students and researchers. While the 
Nature Reserves Board was active (1951-1990), researchers had to apply directly to the Board for permission to conduct research in Bukit Timah. Many of the research projects were by undergraduates from the University of Singapore. In the period from 1960 to 1972 there were projects on isopods, millipedes, collembolans, mosquitos, ants, invertebrates living in association with ants, the vertical stratification of flying insects, ferns, seedling growth, the decomposition of leaf litter, and soil-living protozoans and nematodes. Several individuals applied for permission to collect as a basis for writing books. In the next period, research permits concerned largely butterflies, but also bees and wasps, potter wasps, dragonflies, other insects, soil and water sampling, plant galls, figs, plant collections for laboratory classes and herbarium, and Globba leucantha Miq. var. peninsularis Holttum (still surviving in 1973 as a small cluster of plants about $200 \mathrm{~m}$ below the junction of Upper Quarry Road, even then declining but still just hanging on within the primary forest zone: see Ho et al., 2019). Collection permits (rather than research permits) continued to be issued by the Nature Reserves Board, using a standard reply form; records survive through the 1980s but as they do not specify the topic they cannot be used for a detailed analysis. Numerous applications from butterfly collectors had to be rejected.

Much of the research done in the 1990s and early 2000s was botanical. Turner (1994) analysed the flora, and a checklist of the flora of Bukit Timah was prepared (Turner \& Chua, 2011). In 1992 a 2 ha Forest Dynamics Plot was set up by the Nanyang Technological University and the then Centre for Tropical Forest Science, Smithsonian Institution, in collaboration with the National Parks Board. More than 12,000 trees measuring more than $1 \mathrm{~cm}$ diameter have been mapped, measured and identified, and re-measured every few years (LaFrankie et al., 2005). Now running for more than 25 years, it has become one of the most historically important research projects ever carried out in the nature reserve.

During the period from 2004 to 2017 inclusive, the National Parks Board issued 392 permits for new research either in the nature reserve or more broadly in Singapore but with the nature reserve as one of the sites covered. The recent average has been about 25-30 permits relevant to Bukit Timah each year, equivalent to two or three new projects every month. In addition, there were many renewals of existing permits or additions to the personnel included on permits. (Many further permits were of course issued for research elsewhere in Singapore.) A list of all such permits/projects is maintained by the National Biodiversity Centre. In principle, every project should result in a report being lodged with the National Biodiversity Centre so as to provide a record both of work done and results obtained, preferably with a record of where collected specimens are lodged. The purpose of the system is not meant to be one of control, but of coordination, information and compilation, so that clashes in timetabling can be avoided, and staff can know who to allow to collect specimens or bring equipment or who to call in case of emergency. Because there are several projects beginning in every month, and each may last from several months to several years, there are many research projects running concurrently at all times.

The research topics pursued during the period 2004-2017 have been summarised in Table 2. There were 112 permits issued regarding plants, 90 on vertebrates, 126 


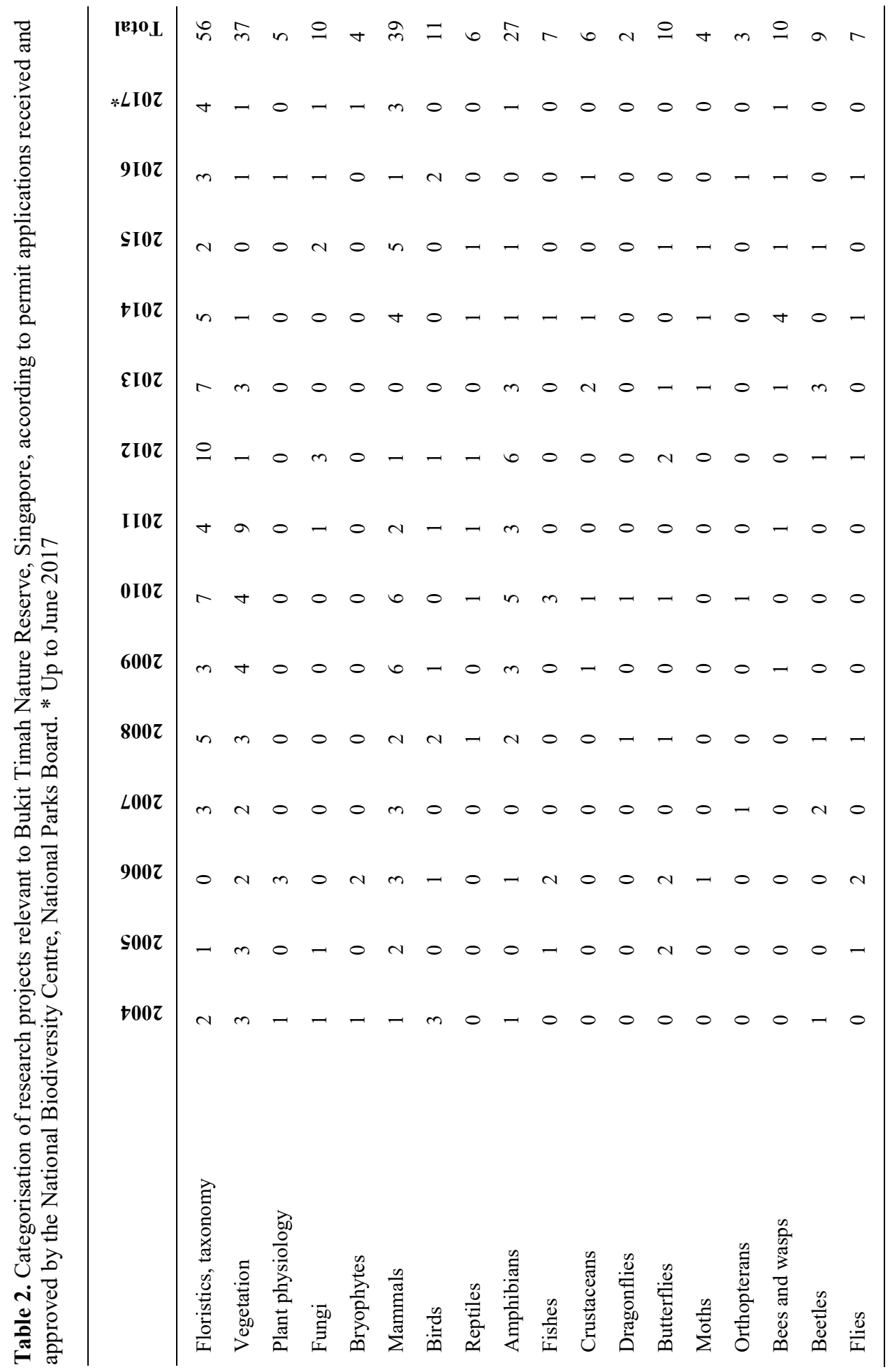




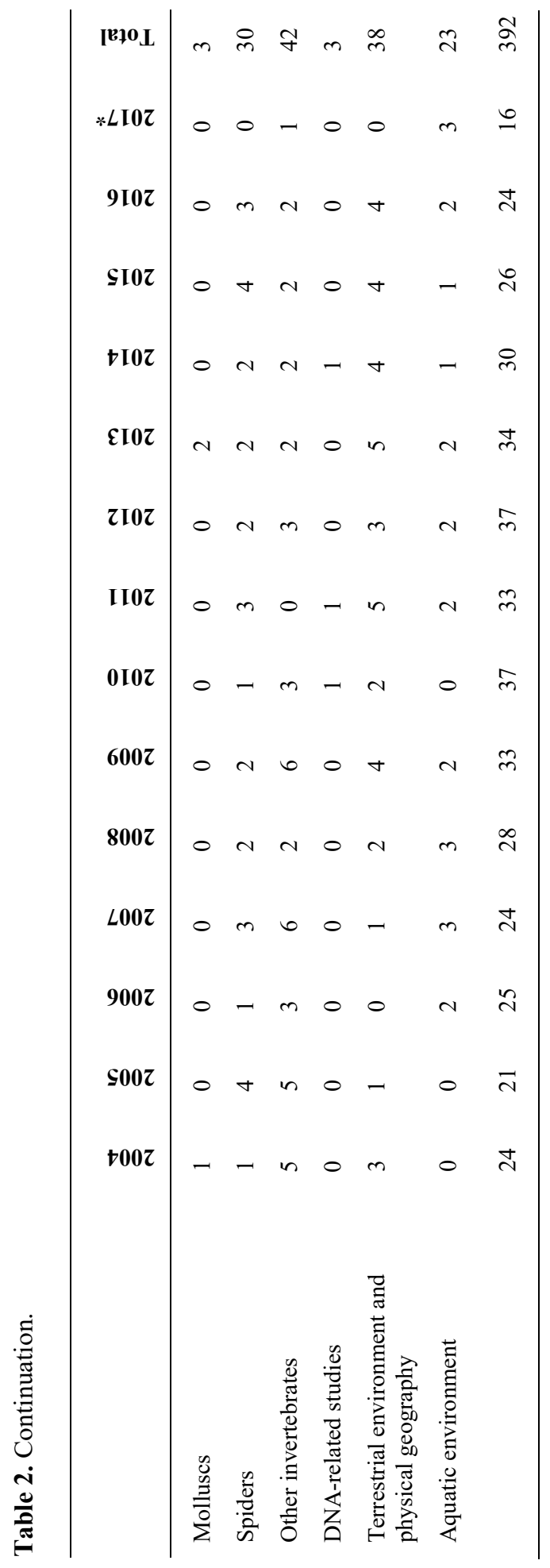


on invertebrates, and 61 on the terrestrial and freshwater environment. Those figures conceal large skews towards popular research subjects, for example, mammals accounted for $43 \%$ of all the research permits issued for vertebrates, and among mammals the most frequently studied species were flying lemur Galeopterus variegatus and long-tailed macaque Macaca fascicularis.

ACKNOWLEDGEMENTS. We thank Mr. Wong Tuan Wah, Sharon Chan, Lena Chan, Cheryl Chia and Sunia Teo of the National Parks Board for help and information. Lena Chan and the library staff of Singapore Botanic Gardens provided access to historical documents. Jayasri Lakshminarayanan, National Biodiversity Centre, helped to compile the list of research permits that is analysed in Table 1.

\section{References}

Ashton, P.S. (2013). A view from the trees. Raffles Bull. Zool. (Suppl. 29): 41-47.

Barnard, T.P. (2014). Nature Contained: Environmental histories of Singapore. Singapore: NUS Press.

Barnard, T.P. (2016). Nature's Colony: Empire, nation and environment in the Singapore Botanic Gardens. Singapore: NUS Press.

Cai, Y. (2019). Hydrogeomorphic characteristics of streams in Bukit Timah Nature Reserve, Singapore. Gard. Bull. Singapore 71 (Suppl. 1): 441-490.

Cantley, N. (1887). Report on the Forests of the Straits Settlements. Singapore: Government Printing Office.

Carter, W.L. (1900). Report on the Forest Reserves, Singapore, for the Year 1899. Singapore: Government Printing Office.

Chan, L. \& Davison, G.W.H. (2019). Introduction to the Comprehensive Biodiversity Survey of Bukit Timah Nature Reserve, Singapore, 2014-2018. Gard. Bull. Singapore 71 (Suppl. 1): 3-17.

Corlett, R.T. (1991). Vegetation. In: Chia, L.S., Ausafur Rahman \& Tay, D.B.H. (eds) The Biophysical Environment of Singapore, pp. 134-154. Singapore: Singapore University Press.

Corlett, R.T. (1992). The ecological transformation of Singapore, 1819-1990. J. Biogeogr. 19: 411-420.

Corlett, R.T. (1995). The history of Bukit Timah Nature Reserve. Rain Forest in the City: Bukit Timah Nature Reserve, Singapore. Gard. Bull. Singapore (Suppl. 3): 7-10.

Corner, E.J.H. (1938). Annual Report of the Director of Gardens for the Year 1937. Singapore: Government Printing Office.

Deyrolle, H. (1864). Description des Buprestides de la Malaisie recueillés par M. Wallace pendant son voyage dans cet Archipel. Ann. Soc. Entomol. Belg. 8: 1-280, 4 plates.

Fox, W. (1895). Report on the Gardens and Forest Departments, Straits Settlements, for the Year 1894. Singapore: Government Printing Office.

Fox, W. (1902). Annual Report on the Botanic Gardens, Singapore, for the Year 1901. Singapore: Government Printing Office.

Gupta, A. (1992). Physiography of the Bukit Timah Nature Reserve and the Central Water Catchment area: a preliminary report. Unpublished report. Reports on the Nature Reserves Survey (Phase I). Singapore: National Parks Board. 
Henderson, M.R. (1951). Botanic Gardens Department Annual Report for 1950. Singapore: Government Printing Office.

Henderson, M.R. (1952). Botanic Gardens Department annual report for 1951. Singapore: Government Printing Office.

Hewitson, W.C. (1865). A list of diurnal Lepidoptera collected by Mr. Wallace in the Eastern Archipelago. J. Linn. Soc. Lond. 8: 143-149.

Ho, B.C., Lua, H.K., Bazilah Ibrahim, Yeo, R.S.W., Athen, P., Leong, P.K.F., Ali Ibrahim, Koh, S.L., Hassan Ibrahim, Lindsay, S., Chin, L.L., Seah, W.W. \& Middleton, D.J. (2019). The plant diversity in Bukit Timah Nature Reserve, Singapore. Gard. Bull. Singapore 71 (Suppl. 1): 41-134.

Holttum, R.E. (1940). Annual Report of the Director of Gardens for the Year 1939. Singapore: Government Printing Office.

Innes, J.R. (1896). Report on the Forest Reserves, Singapore, for the Year 1895. Singapore: Government Printing Office.

LaFrankie, J.V., Davies, S.J., Wang, L.K., Lee, S.K. \& Lum, S.K.Y. (2005). Forest Trees of Bukit Timah: Population ecology in a tropical forest fragment. Singapore: Simply Green.

Lee, K.W. \& Zhou, Y. (2009). Geology of Singapore, $2^{\text {nd }}$ ed. Singapore: Defence Science \& Technology Agency.

Lum, S. \& Sharp, I. (eds) (1996). A View from the Summit: The story of Bukit Timah Nature Reserve. Singapore: Nanyang Technological University, National University of Singapore and National Parks Board.

Lye, L.H. (1991). Wildlife protection laws in Singapore. Singapore J. Legal Stud. 1991: 287-319.

MEWR. (2006). Singapore Green Plan 2012, 2006 ed. Singapore: Ministry of the Environment and Water Resources. Available from unpan1.un.org/intradoc/groups/ public/documents/apcity/unpan026598.pdf. Accessed 10 Nov. 2018.

Michell, W.C. (1898). Report on Forest Reserves, Singapore, for the Year 1897. Singapore: Government Printing Office.

Pascoe, F.P. (1864-1869). Longicornia Malayana; or, a Descriptive Catalogue of the Species of the three Longicorn Families Lamiidae, Cerambycidae and Prionidae collected by Mr. A. R. Wallace in the Malay Archipelago. Trans. Entomol. Soc. Lond., $3^{\text {rd }}$ ser., 3: 1-712.

Purseglove, J.W. (1956). Annual Report of the Botanic Gardens Department for 1955. Singapore: Government Printing Office.

Purseglove, J.W. (1957). Annual Report of the Botanic Gardens Department for 1956. Singapore: Government Printing Office.

Ridley, H.N. (1890). Annual Report on the Botanic Gardens and Forest Department, for the Year 1889. Singapore: Government Printing Office.

Ridley, H.N. (1891). Annual Report on the Botanic Gardens and Forest Department, for the Year 1890. Singapore: Government Printing Office.

Ridley, H.N. (1893). Report on the Gardens and Forests Department, Straits Settlements, 1892. Singapore: Government Printing Office.

Ridley, H.N. (1894). Report on the Gardens and Forests Department, Straits Settlements, 1893. Singapore: Government Printing Office.

Ridley, H.N. (1900). Annual Report of the Botanic Gardens, Singapore [1899]. Singapore: Government Printing Office.

Ridley, H.N. (1901). Annual Report on the Botanic Gardens, Singapore, for the Year 1900. Singapore: Government Printing Office. 
Ridley, H.N. (1903). Annual Report on the Botanic Gardens, Singapore, for the Year 1902. Singapore: Government Printing Office.

Ridley, H.N. (1922-1925). The flora of the Malay Peninsula, 5 vols. London: L. Reeve \& Co. Smith, F. (1857). Catalogue of the hymenopterous insects collected at Sarawak, Borneo; Mount Ophir, Malacca; and at Singapore, by A.R. Wallace. J. Proc. Linn. Soc. Lond. Zool. 2(6-7): 42-88.

Smith, F. (1858). Catalogue of the hymenopterous insects collected at Sarawak, Borneo; Mount Ophir, Malacca; and at Singapore, by A.R. Wallace. J. Proc. Linn. Soc. Lond. Zool. 2(6-7): 89-130.

Smith, F. (1863). Notes on the Geographical Distribution of the Aculeate Hymenoptera collected by Mr. A. R. Wallace in the Eastern Archipelago. J. Proc. Linn. Soc. Lond. Zool. 7: 109-145.

Tan, H.T.W., Chou, L.M., Yeo, D.C.J. and Ng, P.K.L. (2010). The Natural Heritage of Singapore. Singapore: Prentice Hall.

Turner, I.M. (1994). The taxonomy and ecology of the vascular plant flora of Singapore: a statistical analysis. Bot. J. Linn. Soc. 114: 215-227.

Turner, I.M. \& Chua, K.S. (2011). Checklist of the Vascular Plant Species of the Bukit Timah Nature Reserve. Singapore: Raffles Museum of Biodiversity Research, Department of Biological Sciences, National University of Singapore.

Van Whye, J. (2014). Wallace in Singapore. In: Barnard, T.P. (ed.) Nature Contained: Environmental histories of Singapore, pp. 85-109. Singapore: NUS Press.

Walker, F. (1856a). Catalogue of the Dipterous Insects collected at Singapore and Malacca by Mr. A. R. Wallace, with Descriptions of New Species. J. Proc. Linn. Soc. Lond. Zool. 1: 4-39.

Walker, F. (1856b). Catalogue of the Homopterous Insects collected at Singapore and Malacca by Mr. A. R. Wallace, with Descriptions of New Species. J. Proc. Linn. Soc. Lond. Zool. 1: 82-96.

Walker, F. (1856c). Catalogue of the Homopterous Insects collected at Singapore and Malacca by Mr. A. R. Wallace, with Descriptions of New Species. J. Proc. Linn. Soc. Lond. Zool. 1: $97-100$.

Walker, F. (1859). Catalogue of the Heterocerous Lepidoptera collected at Singapore by Mr. A. R. Wallace, with Descriptions of New Species. J. Proc. Linn. Soc. Lond. Zool. 3: $183-196$.

Wallace, A.R. (1869). The Malay Archipelago: The land of the Orang-Utan, and the bird of paradise. A narrative of travel, with studies of man and nature, vol. 1. London: Macmillan and Co. 